\title{
Recolonization pattern of the polychaete Lanice conchilega on an intertidal sand flat following the severe winter of 1995/96
}

Received: 24 May 2000 / Received in revised form: 7 May 2001 / Accepted: 8 May 2001 / Published online: 12 July 2001 C) Springer-Verlag and AWI 2001

\begin{abstract}
The recolonization process of Lanice conchilega was studied on an intertidal sand flat in the northern Wadden Sea after an intertidal population had been wiped out during the severe winter of 1995/96. After very low recruitment in the first two years, the population fully recovered in the third year after its destruction. By then, the distribution pattern closely resembled the pattern before the severe winter with $>95 \%$ of all Lanice occurring below $-0.5 \mathrm{~m}$ mean tidal level and dominance of the density categories 6-50 individuals (ind) $\mathrm{m}^{-2}$ and 51-200 ind $\mathrm{m}^{-2}$. Lanice larvae have been observed to attach preferentially on the tubes of adults. However, the high recruitment in the third year was also seen in areas devoid of adult Lanice, indicating that settlement facilitation by adults was of little importance for the recolonization process. Instead, we suggest that the observed recruitment pattern was a consequence of a large-scale decline in the metapopulation in the tidal basin and the onshore coastal subtidal which resulted in insufficient larval supply onto the tidal flats and low recruitment in the first two years following the severe winter.
\end{abstract}

Keywords Lanice conchilega · Winter effects · Recolonization $\cdot$ Recruitment $\cdot$ Population dynamics

\section{Introduction}

The sand mason, Lanice conchilega, is a widespread polychaete that belongs in the top ten species with respect to its contribution to macrozoobenthic biomass in the intertidal Wadden Sea (Beukema 1976; Beukema et al. 1978). It is typically found in the intertidal and shal-

Communicated by H.-D. Franke

M. Strasser ( $)$ U. Pieloth

Foundation Alfred Wegener Institute for Polar

and Marine Research, Wadden Sea Station Sylt, 25992 List,

Germany

e-mail: mstrasser@awi-bremerhaven.de

Tel.: +49-4651-956136, Fax: +49-4651-956200 low subtidal (Ziegelmeier 1969) and builds very characteristic tubes, made from cemented sand grains and shell fragments. The top of the tube usually carries a ragged fringe that projects a few centimetres out of the sediment. The tubes may have either a blind ending down in the sediment (I-shape) or may be U-shaped or W-shaped, in which case a second ragged fringe may appear on the sediment surface (Seilacher 1951; Ziegelmeier 1969).

The population dynamics of Lanice is characterized by conspicuous spatial and temporal heterogeneity. Lanice has been found to establish dense clusters of up to 10,000 ind $\mathrm{m}^{-2}$ in the intertidal (Ziegelmeier 1952; Hertweck 1995) and of about 20,000 ind $\mathrm{m}^{-2}$ in the subtidal (Buhr 1979). In a long-term study in the western part of the Wadden Sea, the abundance of Lanice showed the highest variability between years of all the species studied (Beukema et al. 1983). This variability is caused by its high sensitivity to cold winters. Lanice usually occurs in high abundances during periods with mild winters and in low abundances after cold winters (Beukema 1990, 1992). After exceptionally hard winters, Lanice populations regularly suffer mass mortality: during the winter of 1962/63 in the German Bight (Ziegelmeier 1964) and in the intertidal zone of south and south east England (Crisp 1964); during the winter 1978/79 in the Dutch part of the Wadden Sea (Beukema 1979) and in the Weser Estuary (Buhr 1981); during the winter of 1995/96 in the intertidal and subtidal zone of Lower Saxony (Günther and Niesel 1999) and in the intertidal of Schleswig-Holstein (this study). A meteorological characterization of the winter 1995/96 in the northern Wadden Sea is given in Martens (2001)

Despite the striking importance of such mass mortalities for the population dynamics of Lanice, the recolonization process has never been investigated in detail in the field. After a massive Lanice population in the Weser Estuary was destroyed during the winter of $1978 / 79$ we only know recolonization had not taken place until July 1980 (Buhr 1981). After the elimination of Lanice on intertidal flats near Spiekeroog (Lower Saxony) during the winter of 1995/96, the population had not recovered in 
Fig. 1 Sampling grid with 206 stations in Oddewatt near the island of Sylt in the northern Wadden Sea (German Bight). Isolines indicate tidal level $(+/-0=$ mean tidal level, $-1=$ mean low-tide level)

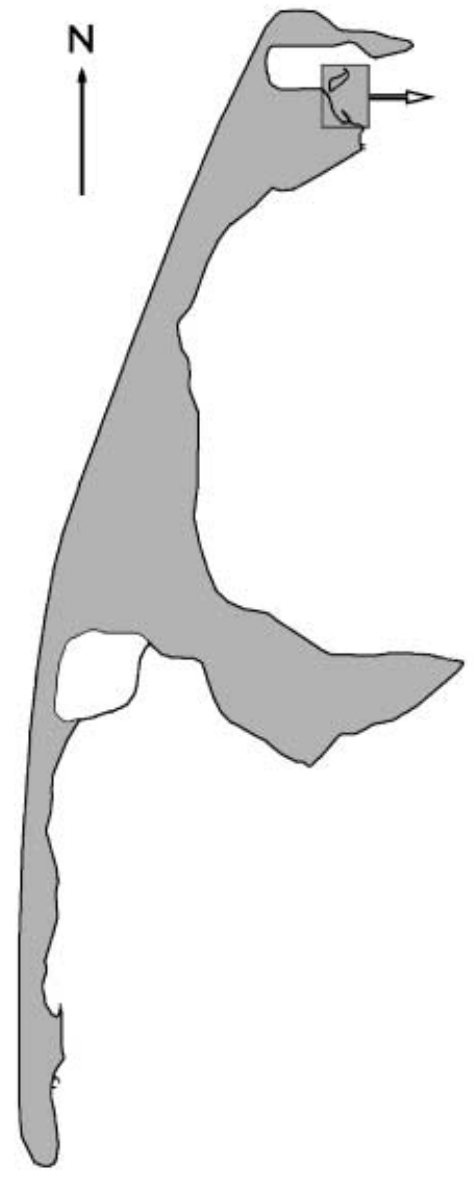

1996 (Günther and Niesel 1999). Based on a study by Hertweck (1995) in the Spiekeroog area it is presumed that the distribution pattern of Lanice is re-established within 3 or 4 years (Heuers et al. 1998). In the Dutch Wadden Sea, Lanice usually reached nearly normal levels of abundance within 1-2 years after severe winters (Beukema 1990).

Here we present a 4-year study where we mapped Lanice abundance on a kilometre scale in the year before and in the three years after the severe winter of 1995/96. The detailed mapping approach enabled us to determine (1) how long it took until an intertidal Lanice population fully recovered after a winter elimination and (2) to what extent the recolonization pattern resembled the spatial pattern before the die-off. Recruitment of Lanice seems to depend to some extent on promotion by adults since larvae of Lanice have been described as settling preferentially on the tubes of adult worms (Carey 1987; Pieloth 1996; Heuers et al. 1998). As these tubes were missing after the severe winter we expected a low recruitment immediately after the die-off and a gradual increase of Lanice in the following years, leading eventually to former densities.

\section{Methods}

The study was conducted in "Oddewatt", a large intertidal area of Königshafen about $1 \mathrm{~km}^{2}$ in size, which is situated at the north of the island of Sylt in the northern Wadden Sea (Fig. 1). The Königshafen is part of the Sylt-Røm $\varnothing$ Bight. The water exchange with the North Sea is confined to a narrow tidal inlet between the islands Sylt and Røm $\varnothing$. The tides are semidiurnal with a mean tidal range of about $2 \mathrm{~m}$. More information about the bight is given in Gätje and Reise (1998). The Oddewatt was chosen as the study area because it has generally been populated by high numbers of Lanice in the past (Reise 1985).

For mapping purposes the Oddewatt was divided into a rectangular grid with $50 \mathrm{~m}$ grid point distance, resulting in 206 sampling stations (Fig. 1). The sampling stations were assigned to four tidal levels: high intertidal (above $-0.5 \mathrm{~m}$ mean tidal level $=$ MTL), mid-intertidal ( $-0.5 \mathrm{~m}$ to $-0.8 \mathrm{~m}$ MTL), low intertidal $(-0.8 \mathrm{~m}$ to $-1.0 \mathrm{~m}$ MTL), and shallow subtidal (below $-1.0 \mathrm{~m}$ MTL). The shallow subtidal was only accessible at spring low tides. Half of the stations were located in the high intertidal (103 stations), $28 \%$ in the mid-intertidal (58 stations), $12 \%$ in the low intertidal (24 stations), and $10 \%$ in the shallow subtidal ( 21 stations).

\section{Abundance of Lanice}

Abundance of Lanice was determined in July/August 1995, September 1996, October/November 1997, and November 1998 based on counts of the visible fringes of the tubes above the sediment surface. Since a single Lanice may build more than one fringe, it was necessary to determine the relation between the number of visible fringes above the surface and the actual number of Lanice 
Fig. 2 Number of live Lanice below $0.0225 \mathrm{~m}^{-2}$ versus number of visible fringes above the sediment. Indicated are linear regression line (solid line) and a fringe:Lanice ratio of 1 (broken line)

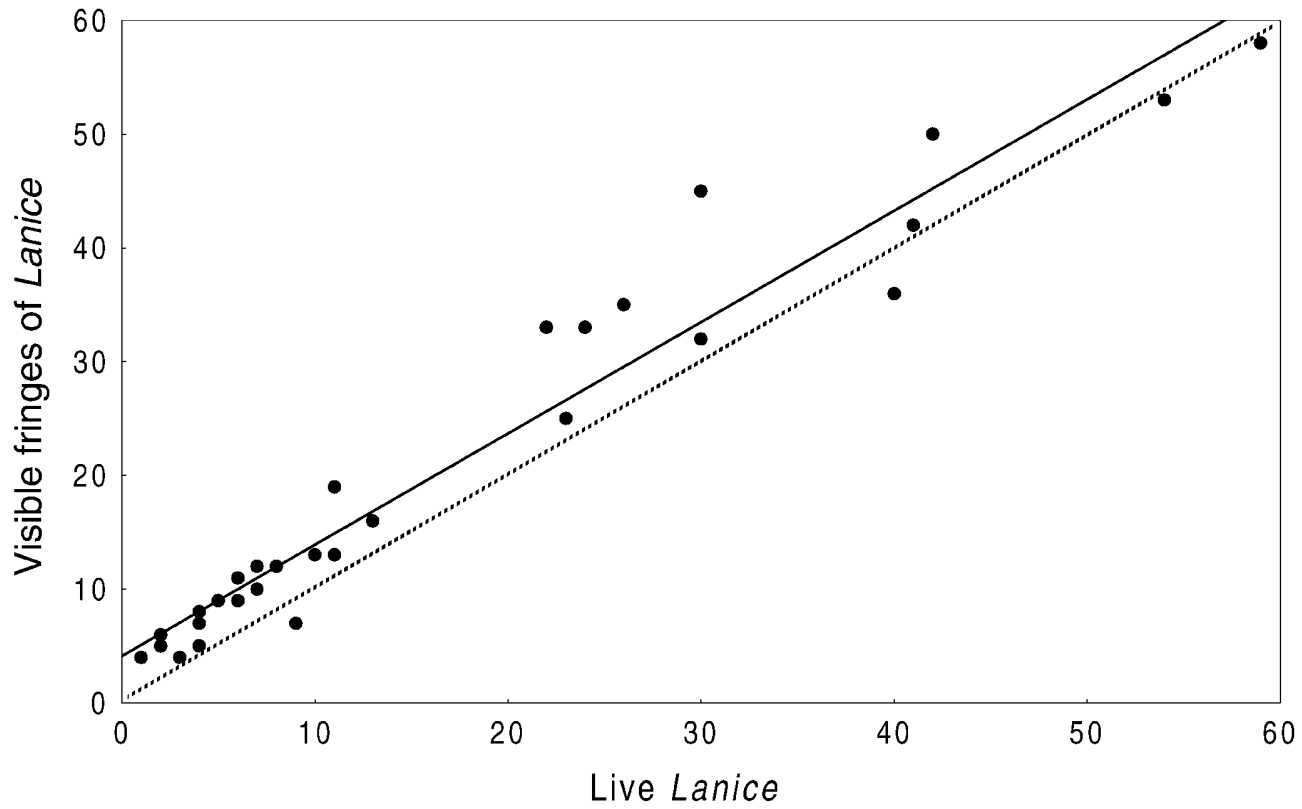

in the sediment in order to obtain a more reliable estimate of the population density. To this end, we determined the ratio between visible fringes and live Lanice at 30 sites with different Lanice densities in October/November 1995 in the low intertidal zone. At each site the sediment was excavated down to $30 \mathrm{~cm}$ using a boxcorer of $0.0225 \mathrm{~m}^{2}$ and both the number of visible fringes above the sediment and the number of live Lanice inside the core were counted. The number of live worms was significantly correlated with the number of visible fringes (Spearmans $r=0.97, n=30$, $P<0.001)$ and the line of best fit was almost parallel to a hypothetical fringe:Lanice ratio of 1 (Fig. 2). This indicates that the shape of Lanice tubes (I-, U- or W-type) was independent from density in the tested range. The mean fringe:Lanice ratio of the 30 sites was 0.73 with an average deviation of $24 \%$ from this mean. Abundance of Lanice for each of the 206 stations was finally estimated by counting all visible fringes in ten randomly placed quadrats of $0.0625 \mathrm{~m}^{2}$ and multiplying the mean with the correction factor of 0.73 . In addition to the mapping procedure, the study area was visited at least once a month between March and November each year so as not to miss any sudden major changes in population densities.

\section{Results}

Distribution of Lanice before and after the ice winter of 1995/96

In summer 1995 the spatial pattern of the Lanice population was characterized by a patchy distribution with a dominance of the density categories $6-50$ ind $\mathrm{m}^{-2}$ and 51-200 ind $\mathrm{m}^{-2}$ (Fig. 3). Only two patches with densities $>200$ ind $\mathrm{m}^{-2}$ existed with a maximum of 386 ind $\mathrm{m}^{-2}$ at one station. Average population density for the entire area amounted to 30.4 ind $\mathrm{m}^{-2}$. More than $99 \%$ of all Lanice were found below $-0.5 \mathrm{~m}$ MTL. This population was completely eliminated by the severe winter of 1995/96. After the melting of the ice shield in March 1996, empty Lanice tubes were still protruding abundantly out of the sediment but these decayed almost completely until June. In 1996 recruitment of Lanice was very poor. Only few individuals (average of Oddewatt 0.2 ind $\mathrm{m}^{-2}$ ) had recolonized the low intertidal and the shallow subtidal by the end of summer. Although recruitment was slightly higher in 1997 than in 1996, average population density $\left(1.3\right.$ ind $\left.\mathrm{m}^{-2}\right)$ was still much lower than before the ice winter. Maximum values did not exceed 47 ind $\mathrm{m}^{-2}$.

In June of 1998 we observed high recruitment in the study area. Juvenile Lanice could be seen abundantly in the low intertidal but also in the mid- and high intertidal where adult worms were still missing. Occasionally strong easterly winds in summer allowed us to examine the shallow subtidal which usually remains covered by water even at spring low tides. Here, a high recruitment had also taken place in the absence of adult tubes. In November 1998 the recolonization pattern of the population closely resembled the pattern before the winter of 1995/96 (Fig. 3). The average population density in 1998 (30.7 ind $\mathrm{m}^{-2}$ ) was nearly the same as in 1995 , and the density categories 6-50 ind $\mathrm{m}^{-2}$ and 51-200 ind $\mathrm{m}^{-2}$ were again dominant. The maximum value in 1998 was 227 ind $\mathrm{m}^{-2}$. About $97 \%$ of all Lanice were found below $-0.5 \mathrm{~m}$ MTL. A conspicuous similarity between the spatial patterns of 1995 and 1998 also became apparent when abundances for tidal levels were regarded separately (Fig. 4). Highest average abundances were found in the lowest intertidal zone $(-0.8 \mathrm{~m}$ to $-1.0 \mathrm{~m}$ MTL). Average abundances were about $35-40 \%$ lower in the shallow subtidal $(<-1.0 \mathrm{~m}$ MTL) and about $25 \%$ (1995) and $50 \%$ (1998) lower in the mid-intertidal $(-0.5 \mathrm{~m}$ to $-0.8 \mathrm{~m}$ MTL). In all years, abundances were lowest in the highest intertidal zone (>-0.5 m MTL). 
Fig. 3 Distribution of Lanice in Oddewatt near the island of Sylt in 1995-1998

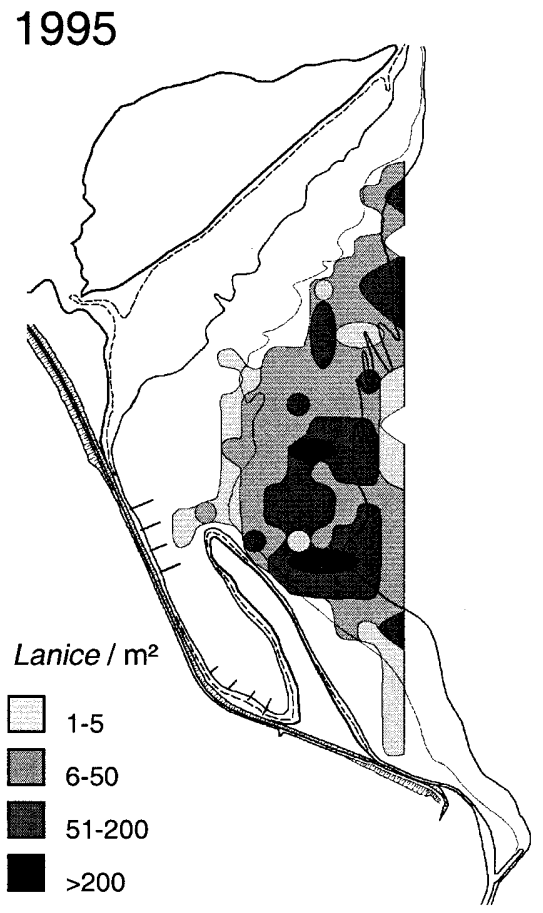

1996

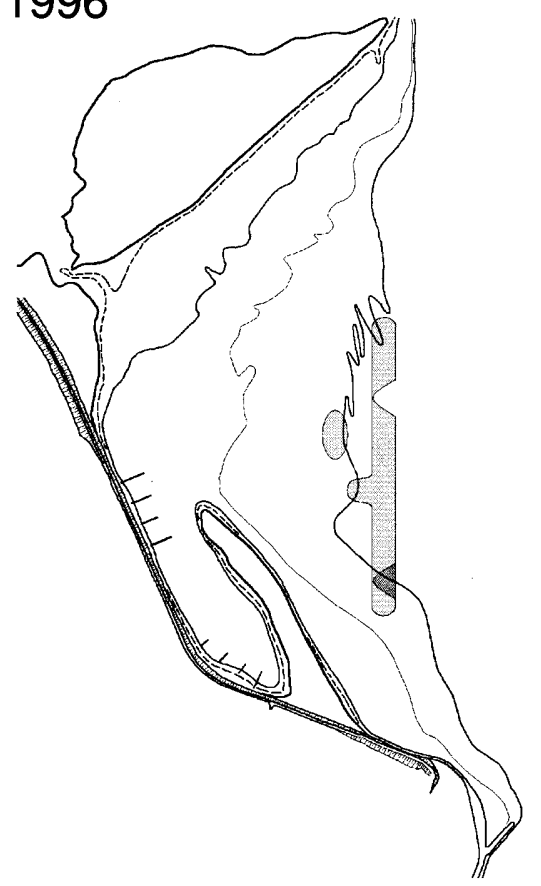

1997

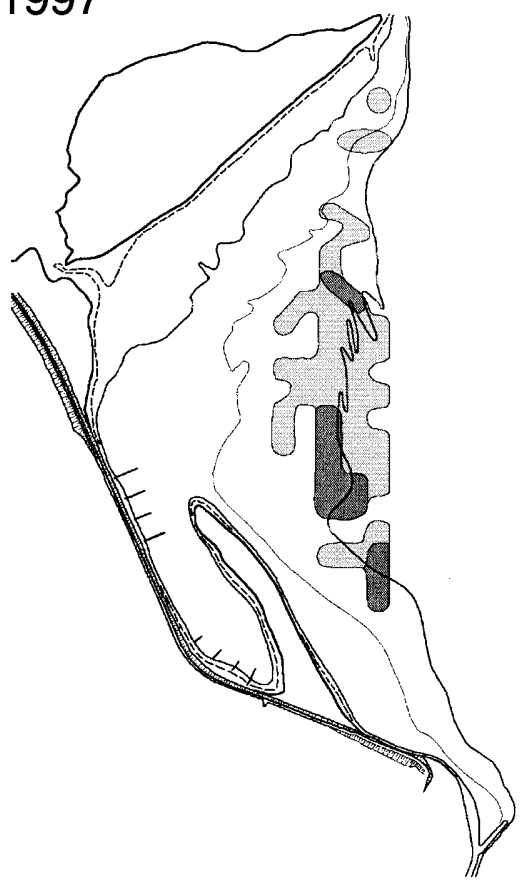

1998

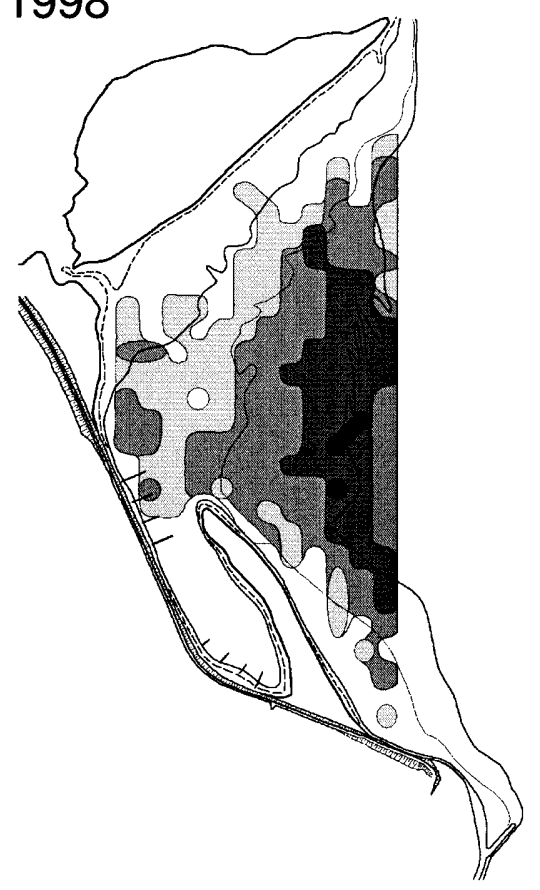

\section{Discussion}

Recolonization pattern after the severe winter of 1995/96

Eliminations of intertidal Lanice populations after severe winters are a well known phenomenon (e.g. Crisp 1964; Beukema 1979; Günther and Niesel 1999). However, this recolonization process has never been studied in detail. In our study it took three years for the Lanice population to recover from elimination by a severe winter.
However, we cannot confirm our hypothesis that the recovery time is governed mainly by a gradual increase in adult worms that facilitate settlement of Lanice larvae. While it has been demonstrated earlier that larvae of Lanice prefer to settle on tubes of adult worms (Carey 1987; Pieloth 1996; Heuers et al. 1998) our results show that promotion of settlement by tubes of adults is not compulsory for high recruitment. After two years of low recruitment, the high recruitment event of Lanice in 1998 took also place in areas where tubes of adults were 


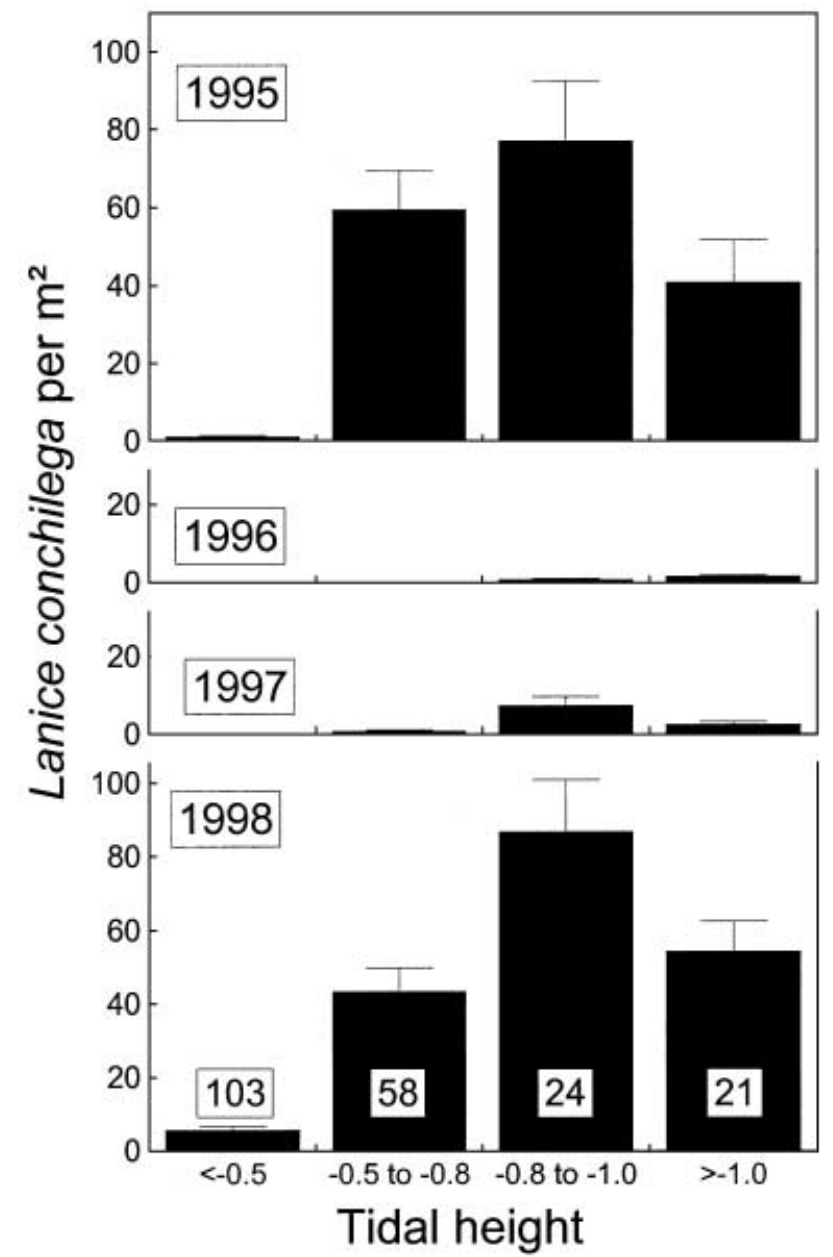

Fig. 4 Mean abundance (+SE) $\mathrm{m}^{-2}$ of Lanice in 1995-1998 in relation to tidal height (m). Number of sampling stations is given inside each box

absent. In field experiments it has been shown that the reported preference of Lanice larvae for tubes of adults to settle on was not caused by chemical cues from the adults because the larvae also settled on artificial tubelike structures like wooden or metal sticks (Heuers et al. 1998) or PVC bristles of yard-brooms (Pieloth 1996). However, in Oddewatt recruitment was also high in areas without tube-like structures or any other conspicuous epibenthic structures. The presence of adult Lanice did not seem to be a requirement for recolonization in the Dutch Wadden Sea either. There, Lanice suffered total mortality during all colder than average winters (Beukema 1979) and even during cold spells in winters that had mean temperatures above average (Beukema 1985). However, Lanice usually reached near-normal levels of abundance within 1-2 years (Beukema 1990). In the year after the severest winter of the twentieth century (1946/47), Kristensen (1957) even observed unusually high abundances of juvenile Lanice in the Dutch Wadden Sea.

As the high recruitment of Lanice in 1998 occurred independently of the presence of adult Lanice, we con- clude that the low recruitment in 1996 and 1997 cannot be explained by the absence of tube-like structures. What other factors may explain the retarded recolonization pattern following mass mortality?

If intertidal populations are wiped out, the recolonization process depends on the larval supply of surviving subtidal Lanice. However, after the severe winter of 1995/96, Lanice was not only eliminated from the intertidal but abundances had also sharply decreased in the onshore coastal subtidal near Sylt and did not recover until 1997 (Armonies et al. 2001). In our study the retarded recolonization of the intertidal sand flat corresponded well with the larval abundance of Lanice in the Sylt-Rømø bight (Strasser 2000; M. Strasser, in preparation). Accordingly, the low recruitment in 1996 was accompanied by a virtual absence of Lanice larvae, whereas an increase in larval abundance in the following years was accompanied by increased recruitment. Therefore, we suggest that the entire metapopulation in the tidal basin and the onshore coastal zone of the North Sea near Sylt was too small in 1996 to release sufficient numbers of larvae to allow recolonization of the intertidal edge of the distributional range of Lanice. After a gradual buildup of the onshore subtidal population within 2 years, enough larvae may be supplied onto the tidal flats in the third year, resulting in high recruitment. Reduced larval abundance in the years immediately after adult populations of Lanice had been killed was also reported by Buhr (1981) as well as Günther and Niesel (1999). Therefore, we suggest that it was the large spatial scale on which winter cold affected the Lanice metapopulation near Sylt that caused the delay in recovery. The quicker recolonization of the intertidal flats in the Dutch Wadden Sea might be caused by a higher survival of the subtidal Lanice stocks during severe winters. Since winter water temperature in the Wadden Sea decreases from southwest to northeast, the negative effects of severe winters to cold-sensitive species are lower in the western than in the northern Wadden Sea (Beukema et al. 1988). If the subtidal Lanice population suffers relatively little damage, then its larval production may be high enough to achieve a successful recolonization of the intertidal flats in the first two years after severe winters. In addition, the western part of the Wadden Sea is further supplied with larvae from the southern North Sea coast where water temperature hardly ever falls below $0^{\circ} \mathrm{C}$ even during severe winters (Beukema et al. 1988).

Our results confirm the assumption in a preliminary simulation model designed to explore the spatial and temporal dynamics of Lanice (Heuers et al. 1998; Grimm 1999), that it takes about 3-4 years until an intertidal population reaches a similar density and distribution pattern as before a severe winter. However, in a refinement of the model it should be taken into account that high recruitment may also take place in the absence of tubes of adults and that larval supply may differ substantially between years. 
Distribution pattern in the intertidal zone

The highest average abundances of Lanice were found in the lowest intertidal zone and in all years more than $90 \%$ of all Lanice were situated in the three zones closest to the low tide line (below $-0.5 \mathrm{~m}$ MTL). These results are in accordance with other studies from the Wadden Sea where high densities of Lanice were restricted to areas below MTL (Wohlenberg 1937; Ziegelmeier 1952; Beukema 1985; Reise 1985; Carey 1987). Abundances gradually decreased in a landward direction. While Lanice was almost absent in the highest intertidal zone in three out of the four years, an average abundance of about 6 ind $\mathrm{m}^{-2}$ in 1998 indicates that abiotic factors do not generally restrict colonization of this tidal level by Lanice. Conceivable factors that may contribute to relatively low Lanice abundances in the higher intertidal are (1) negative interactions with the bioturbating lugworm Arenicola marina that occurs in high densities in the upper tidal zone, (2) lack of epibenthic structures such as shell fragments and Mytilus edulis beds (see Heuers et al. 1998), (3) too low near-bottom flow velocities to allow successful settlement (see Heuers et al. 1998; Grimm 1999) or (4) insufficient settlement due to a decrease in larval supply in a landward direction.

Finally it should be noted that the maximum abundances of 386 ind $\mathrm{m}^{-2}$ in 1995 (before the severe winter) and 227 ind $\mathrm{m}^{-2}$ in 1998 (after full recovery) do not present the carrying capacity of Lanice in the study area, as densities of about 1,000 ind $\mathrm{m}^{-2}$ have been observed in 1977-1978 and 1990-1993 (K. Reise, personal communication).

Acknowledgements We thank Karsten Reise and Werner Armonies for helpful comments on the manuscript. This study was largely funded by the German Federal Ministry of Education and Research (BMBF) under grant 03F0179A. The first author also wishes to express his gratitude to the Hans Böckler Foundation for their support.

\section{References}

Armonies W, Herre E, Sturm M (2001) Effects of the severe winter 1995/96 on the benthic macrofauna of the Wadden Sea and the coastal North Sea near the island of Sylt. Helgol Mar Res 55. DOI 10.1007/s101520100077

Beukema JJ (1976) Biomass and species richness of the macrobenthic animals living on the tidal flats of the Dutch Wadden Sea. Neth J Sea Res 10:236-261

Beukema JJ (1979) Biomass and species richness of the macrobenthic animals living on a tidal flat area in the Dutch Wadden Sea: effects of a severe winter. Neth J Sea Res 13:203-223

Beukema JJ (1985) Zoobenthos survival during severe winters on high and low tidal flats in the Dutch Wadden Sea. In: Gray JS, Christiansen ME (eds) Marine biology of polar regions and effects of stress on marine organisms. Wiley, Chichester, pp $351-361$

Beukema JJ (1990) Expected effects of changes in winter temperatures on benthic animals living in soft sediments in coastal North Sea areas. In: Beukema JJ, Wolff WJ, Brouns JJWM (eds) Expected effects of climatic change on marine coastal ecosystems. (Developments in Hydrobiology 57) Kluwer Academic, Dordrecht, pp 83-92
Beukema JJ (1992) Expected changes in the Wadden Sea benthos in a warmer world: lessons from periods with mild winters. Neth J Sea Res 30:73-79

Beukema JJ, Bruin W de, Jansen JJM (1978) Biomass and species richness of the macrobenthic animals living on the tidal flats of the Dutch Wadden Sea: long-term changes during a period with mild winters. Neth J Sea Res 12:58-77

Beukema JJ, Cadée GC, Hummel H (1983) Differential variability in time and space of numbers in suspension and deposit feeding benthic species in a tidal flat area. Oceanologica Acta, Proceedings 17th EMBS, pp 21-26

Beukema JJ, Dörjes J, Essink K (1988) Latitudinal differences in survival during a severe winter in macrobenthic species sensitive to low temperatures. Senckenb Marit 20:19-30

Buhr KJ (1979) Eine Massenansiedlung von Lanice conchilega (Polychaeta: Terebellidae) im Weser Ästuar. Veröff Inst Meeresforsch Bremerhaven 17:101-149

Buhr KJ (1981) Auswirkungen des kalten Winters 78/79 auf das Makrobenthos der Lanice-Siedlung im Weser Ästuar. Veröff Inst Meeresforsch Bremerhaven 19:115-131

Carey DA (1987) Sedimentological effects and palaeoecological implications of the tube-building polychaete Lanice conchilega Pallas. Sedimentology 34:49-66

Crisp DJ (1964) The effects of the winter of 1962/63 on the British marine fauna. Helgol Wiss Meeresunters 10:313-327

Gätje C, Reise K (eds) (1998) Ökosystem Wattenmeer, Austausch-, Transport- und Stoffumwandlungsprozesse. Springer, Berlin Heidelberg New York

Grimm V (1999) Modelling the spatial and temporal distribution of Lanice conchilega. In: Dittmann S (ed) The Wadden Sea ecosystem, stability properties and mechanisms. Springer, Berlin Heidelberg New York, pp 147-152

Günther C-P, Niesel V (1999) Effects of the ice winter 1995/96. In: Dittmann S (ed) The Wadden Sea ecosystem, stability properties and mechanisms. Springer, Berlin Heidelberg New York, pp 194-205

Hertweck G (1995) Verteilung charakteristischer Sedimentkörper und Benthosbesiedlungen im Rückseitenwatt der Insel Spiekeroog, südliche Nordsee. I. Ergebnisse der Wattkartierung 1988-92. Senckenb Marit 26(1/2):81-94

Heuers J, Jaklin S, Zühlke R, Dittman S, Günther C-P, Hildenbrandt H, Grimm V (1998) A model on the distribution and abundance of the tube building polychaete Lanice conchilega (Pallas, 1766) in the intertidal of the Wadden Sea. Verh Ges Ökol 28:207-215

Kristensen I (1957) Differences in density and growth in a cockle population in the Dutch Wadden Sea. Arch Neerl Zool $12: 351-453$

Martens P (2001) Effects of the severe winter 1995/96 on the biological oceanography of the Sylt-Røm $\varnothing$ tidal basin. Helgol Mar Res 55. DOI 10.1007/s101520100078

Pieloth U (1996) Lage, Struktur und Artenzusammensetzung einer Lanice conchilega (Pallas) - Population im Königshafen von Sylt. Diploma thesis, University of Marburg

Reise K (1985) Tidal flat ecology. Springer, Berlin Heidelberg New York

Seilacher A (1951) Der Röhrenbau von Lanice conchilega (Polychaeta). Senckenbergiana 32:267-280

Strasser M (2000) Rekrutierungsmuster ausgewählter Wattfauna nach unterschiedlich strengen Wintern. PhD thesis, University of Hamburg, Berichte zur Polar- und Meeresforschung 377

Wohlenberg E (1937) Die Wattenmeer-Lebensgemeinschaften im Königshafen von Sylt. Helgol Wiss Meeresunters 1:1-92

Ziegelmeier E (1952) Beobachtungen über den Röhrenbau von Lanice conchilega (Pallas) im Experiment und am natürlichen Standort. Helgol Wiss Meeresunters 4:107-129

Ziegelmeier E (1964) Einwirkungen des kalten Winters 1962/63 auf das Makrobenthos im Ostteil der Deutschen Bucht. Helgol Wiss Meeresunters 10:276-282

Ziegelmeier E (1969) Neuere Untersuchungen über die Wohnröhren-Bauweise von Lanice conchilega (Polychaeta, Sedentaria). Helgol Wiss Meeresunters 19:216-229 